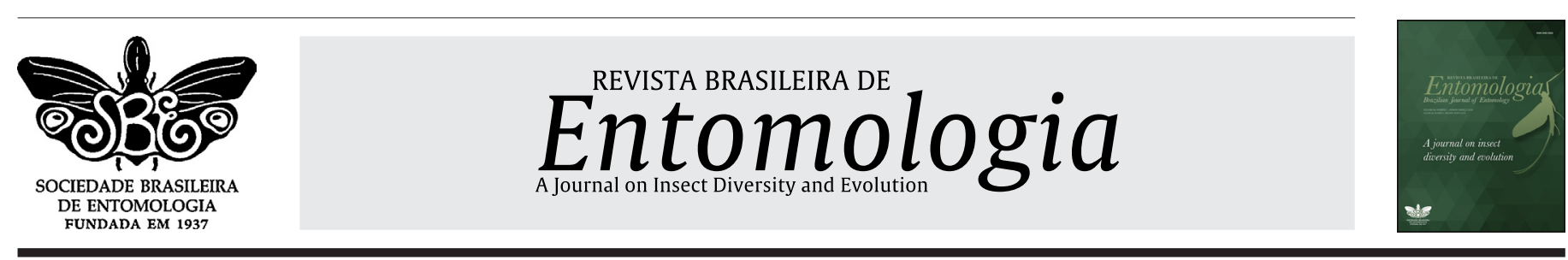

\title{
Sergio Antonio Vanin - a great Brazilian zoologist
}

\author{
Pedro Gnaspini ${ }^{1}$ (D), Cleide Costa ${ }^{2}$, Sônia A. Casari² \\ ${ }^{1}$ Universidade de São Paulo, Instituto de Biociências, Departamento de Zoologia, São Paulo, SP, Brasil. \\ ${ }^{2}$ Universidade de São Paulo, Museu de Zoologia, São Paulo, SP, Brasil.
}

Article history:

Received 11 December 2020 Accepted 14 December 2020

Available online 15 February 2021

Associate Editor: Rodrigo Feitosa
Science loses one of its greatest zoologists. It was with profound sorrow that we learned that Prof. Sergio Antonio Vanin passed away on October 21, 2020, just a few days before his 72nd birthday. The University of São Paulo (USP) and Brazilian entomology have lost an enthusiast in the study and teaching of zoology, especially Coleoptera systematics and species evolution, and a person of extreme common sense, good humor, humbleness of mind, and enormity of heart. He was a kind, ethical person.

This brief report tries to tell a little bit about Prof. Sergio Vanin, as a person and a scientist, and includes a list of his publications, the new taxa and immatures of Coleoptera proposed and described, besides teaching and other activities. We apologize for any oversight in the compilation of Sergio Vanin's extensive legacy.

Sergio Antonio Vanin was born on October 26, 1948, in the city of São Paulo, to José Vanin and Maria Pascalicchio Vanin. He married his colleague of undergraduate course Ana Maria Setubal Pires Vanin, also a professor at USP in the Oceanographic Institute, had two sons, Ricardo and André, and a five year old granddaughter, Nina (Fig. 1A-F).

\section{University education and career}

Sergio's entered higher education after serving in the military with CPOR - Centro de Preparação de Oficiais da Reserva, a branch within the Brazilian Army for the training of officers, where he reached the 2nd lieutenent rank. Regarding this period he used to tell stories with good humor. Actually, his natural enthusiasm for storytelling was essential to his successful teaching career (considering all kinds of activities involved).

Sergio Vanin graduated as a Biologist (holding Teaching and Bachelor degrees, 1968-1971) and obtained the titles of Master (1972-1974) and Doctor (1975-1979) in Zoology from the Institute of Biosciences at USP (IBUSP), conducting his first undergraduate and graduate research mainly at the Museum of Zoology at USP (MZUSP - then tied to the São Paulo State Department of Agriculture).

He conducted and defended his Master's Dissertation (Fig. 2A, 2B) entitled 'Taxonomic Review of South American Belidae (Coleoptera)' ['Revisão Taxonômica dos Belidae Sul-americanos (Coleoptera)'] (published in Vanin, 1976) under the advisement of Dr. Hans Reichardt (MZUSP researcher), with whom he developed a strong personal and scientific relationship, contributing to the study of several coleopterans, especially Torridincollidae (and other Myxophaga) and Curculionidae (and other Curculionoidea). He began research for his Doctoral Thesis (Fig. 2C, 2D) entitled 'Classification, cladistic analysis and geographic distribution of the tribe Erodiscini (Coleoptera, Curculionidae)' [ 'Classificação, análise cladística e distribuição geográfica da tribo Erodiscini (Coleoptera, Curculionidae)'] (published in Vanin, 1986), first under the advisement of Dr. Reichardt, and then, following his advisor's premature death in an accident in 1976, with Dr. Cleide Costa (also a researcher at MZUSP). He conducted most of his PhD study while already serving as a faculty member at IBUSP (see below). He conducted both studies with financial support (scholarships) from the 'São Paulo Research Foundation' ( 'Fundação de Amparo à Pesquisa do Estado de São Paulo' - FAPESP).

Sergio devoted his entire career to the University of São Paulo (USP), especially to the Department of Zoology (DZ), while also maintaining a strong presence at MZUSP. He was invited to a Teaching Assistant position at the DZ in 1975, becoming Assistant Professor (1976), Doctor Assistant Professor (1979), Associate Professor (1997), and Full Professor (2000), and retiring from this position at the end of 2016, after 41 years of teaching. Nevertheless, he continued his research and graduate student advisement following his retirement, serving more than 50 years at USP. His strong ethical stance and liveliness in communicating science have been recognized within the various spheres of the university. In 2018, coinciding with his 70th birthday, the IBUSP Council approved his nomination to receive the title of Professor Emeritus, recognizing his enormous scientific and humanist contributions.

\footnotetext{
* Corresponding author.

E-mail: gnaspini@ib.usp.br (P. Gnaspini).
} 

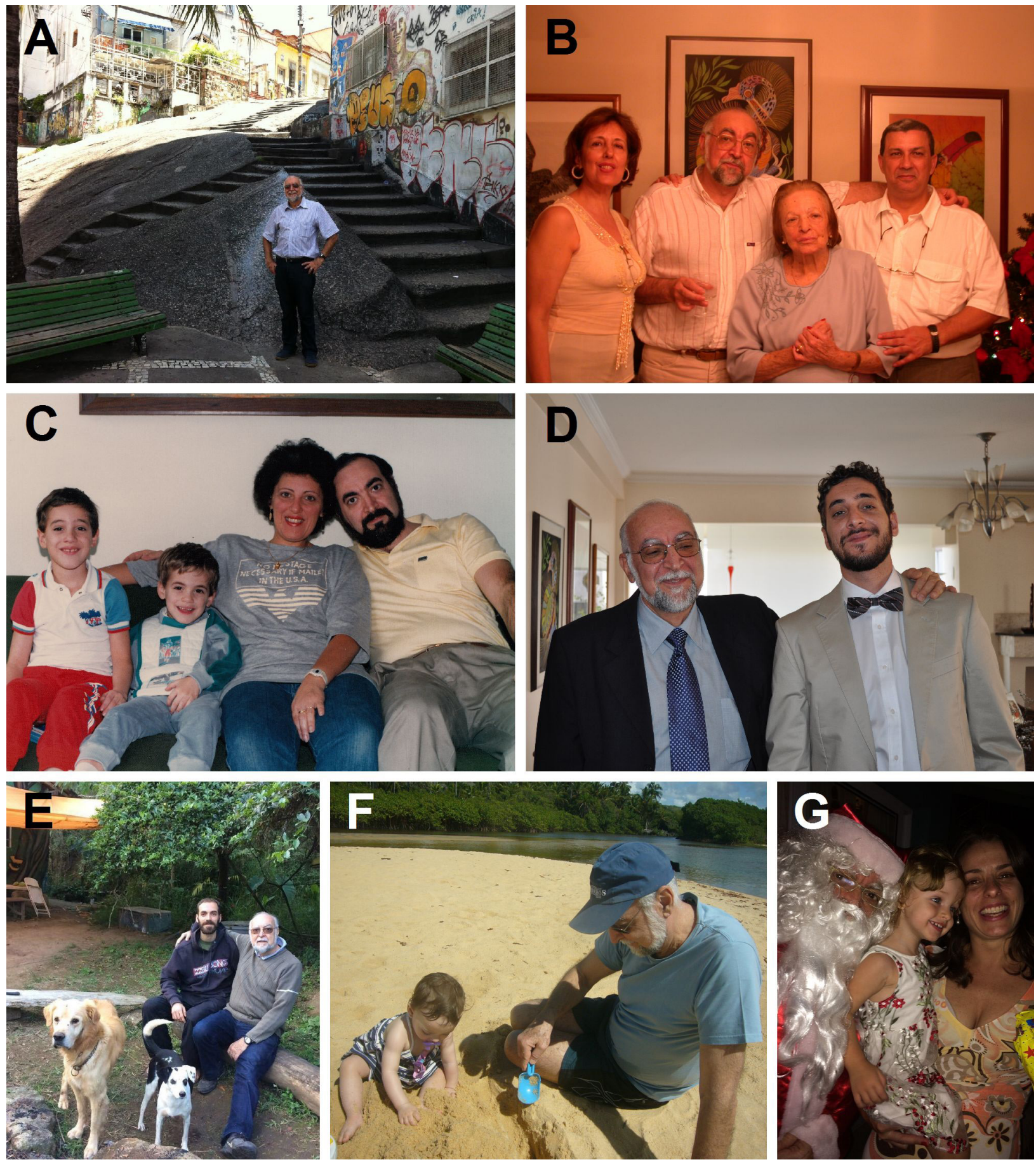

Figure 1 A. Sergio Antonio Vanin. B. Sergio and his mother, Maria, and relatives, Christmas, 2003. C. Sergio, Ana Maria, Ricardo (red clothes), and André (blue clothes). D. Sergio and Ricardo, on his son's wedding day. E. Sergio and André, at his son's house, in Cambuí, Minas Gerais. F. Sergio and Nina, at Trancoso, Bahia. G. Sergio as Santa Claus (with 'grandniece' and her mother).

With regards to undergraduate teaching, Prof. Sergio Vanin always offered to teach general subjects for the training of undergraduates, especially when the institutional need arose. Thus, he taught Animal Ecology (1976-1977), Invertebrate Zoology II (1976-1994), Basic Entomology (1982-2013) (Fig. 3A, 3B), Principles of Systematics and Biogeography (1995-2014) (Fig. 3C), and Fauna, Flora and the Environment (2000), all of which were mandatory courses (except for 'Entomology') in the Biological Sciences curriculum at IBUSP.

Prof. Sergio Vanin's consistent ethical position and integrating vision led him to be unanimously appointed to numerous administrative positions, including Statutory and Non-Statutory Committees both within IBUSP and in other spheres of USP, at crucial times. He was ViceCoordinator of the Graduate Program in Zoology at IBUSP (1986-1990); member (1991-1994) and Vice-President (1993-1994) of the IBUSP Undergraduate Committee during the first major discussion about the Biological Sciences curriculum, which led him to be appointed by the Director as a of Curriculum Restructuring Committee in 1986, culminating in a new curriculum in 1995; Vice-Chair (1995-1999) and Chair (1999-2003) of the DZ; member of the IBUSP Research Committee (2003-2005), serving as Vice-President (2003-2005) and 


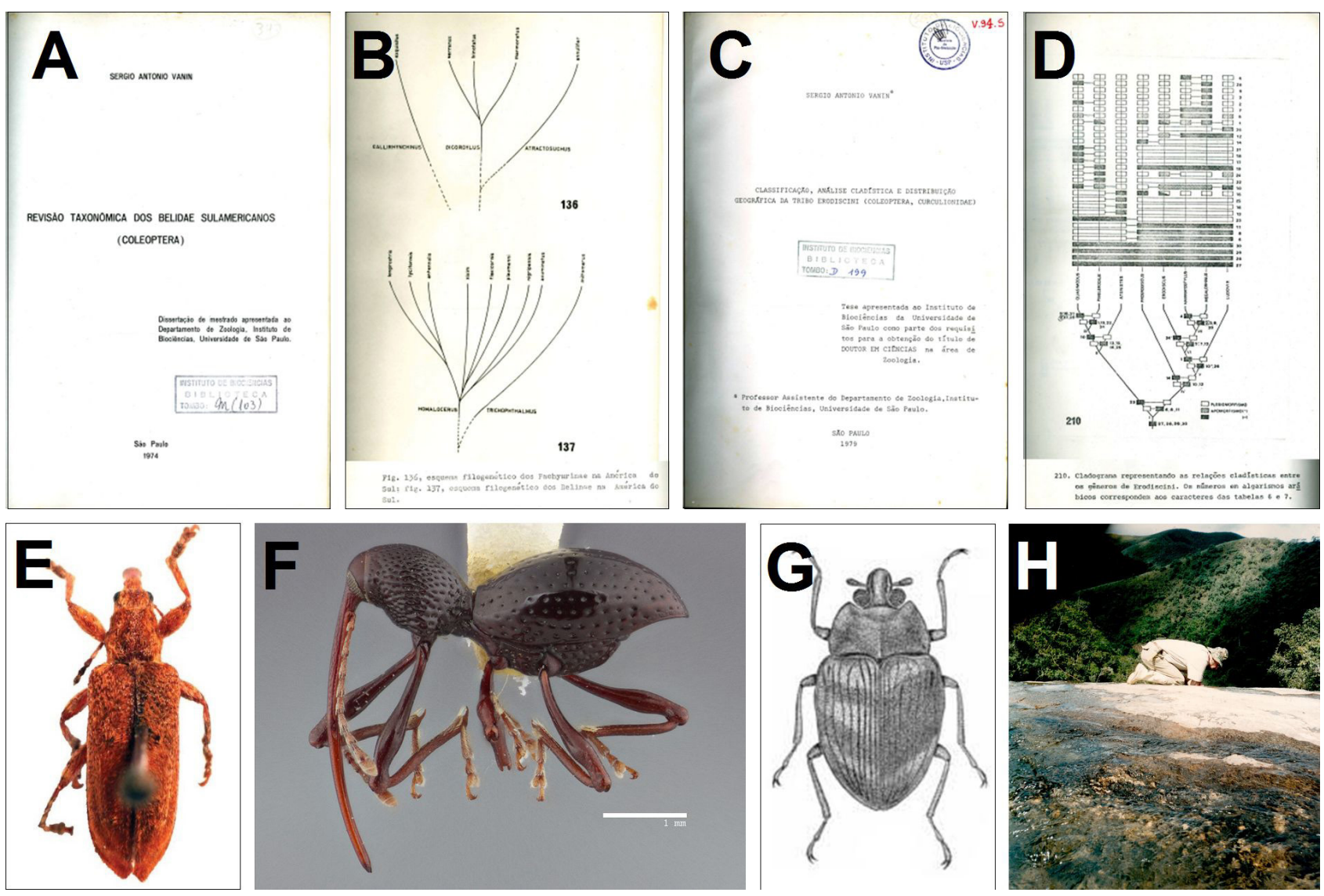

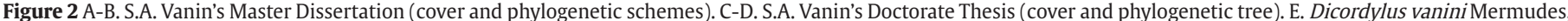

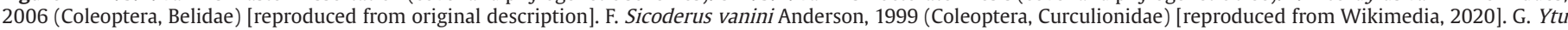
zeus Reichardt, 1973 [reproduced from Vanin, 2011 [webpage by S.A. Vanin]. H. Sergio collecting Torridincollidae beetles.
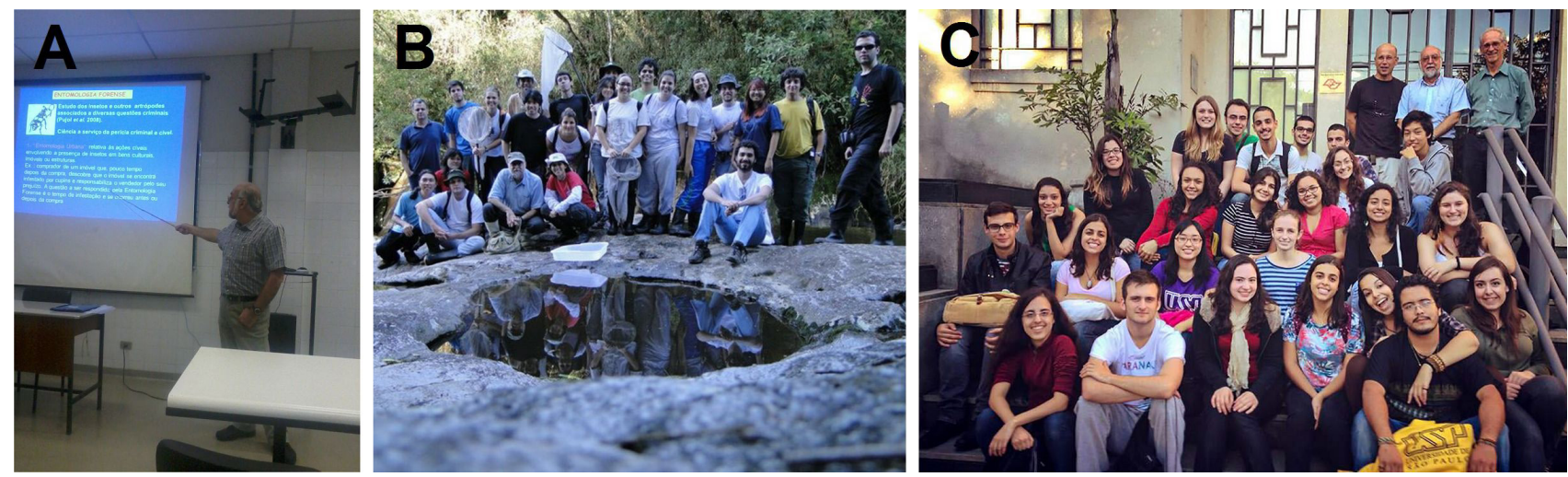

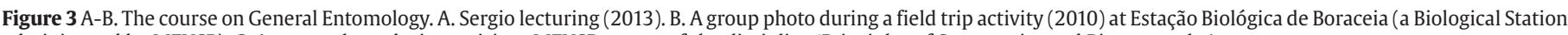
administered by MZUSP). C. A group photo during a visit to MZUSP as part of the discipline 'Principles of Systematics and Biogeography'.

President (2005). Outside IBUSP, he served as Director of the Museum of Zoology at USP (2005-2009), where he also previously served as a member of the Council for several years, and member of the USP Ethics Committee (2010-2013) and USP Faculty Evaluation Committee (2011-2012) as Coordinator of the Sectorial Evaluation Committee in the area of Sciences and Mathematics Teaching.

\section{An Organizer of Nature}

Sergio Vanin was a born naturalist. He derived great pleasure from observing and trying to organize nature, including several 'collector' activities (Fig. 4). In addition to his 'formal' involvement in Coleoptera taxonomy (see below), he had a passion for Mollusca, especially shells, with a relatively deep knowledge of the group and an exquisite collection, having dedicated part of his leisure time to strolling along beaches with his wife in search of specimens and participated in meetings of the Brazilian Society of Conquiliologists (having been honored by this Society - see below, Fig. 6C) and qualification exams and thesis defenses on this taxon. He also had an exquisite (albeit simple, by his assessment) collection of minerals, with samples from around the world.

As part of this naturalist profile, Sergio took great pleasure (and his verve always infected his companions) in fieldwork, regardless of the distances traveled (both to get to the places and on hikes in search of biological material) or adversities faced. His enthusiasm in collecting 

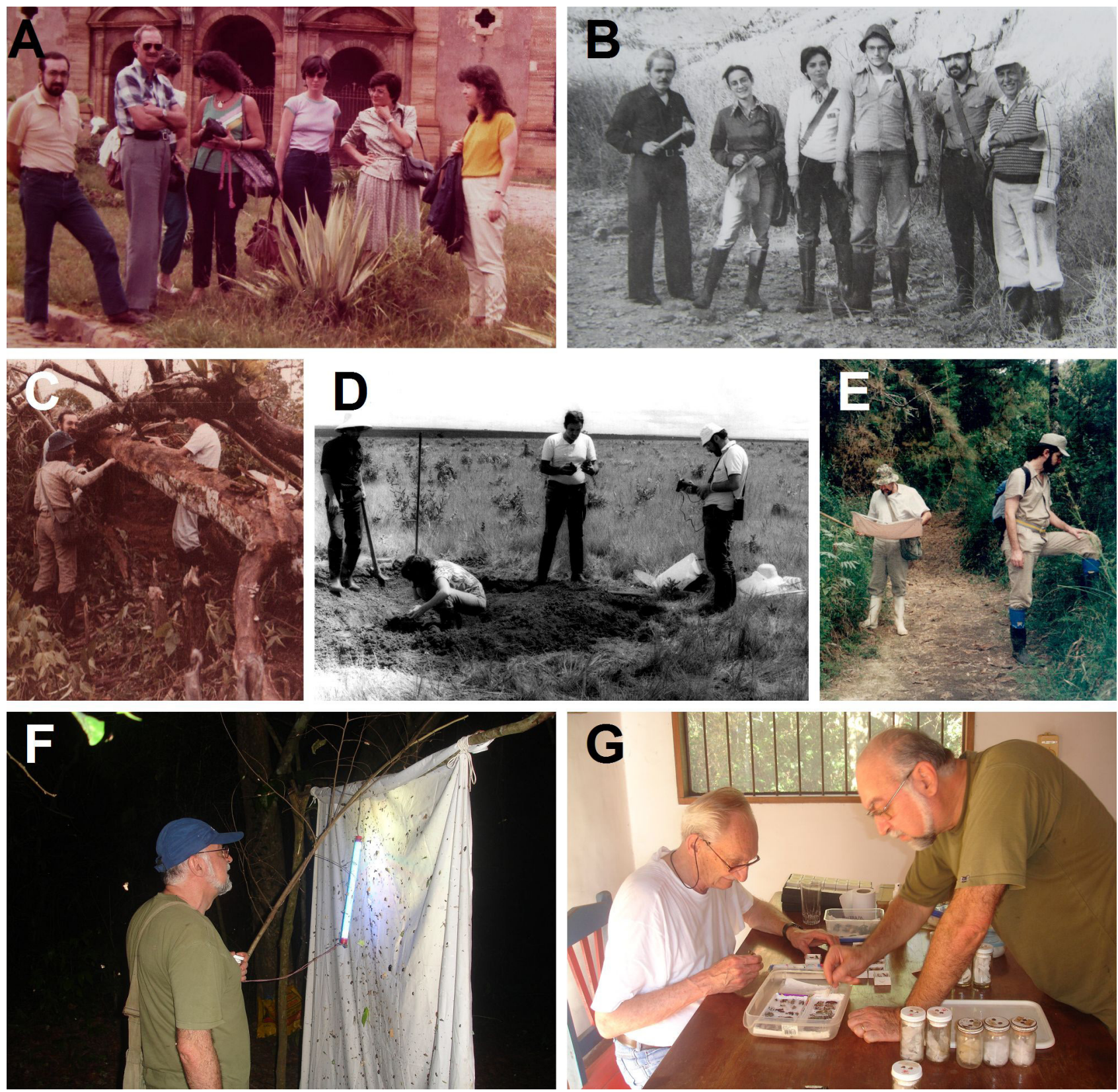

Figure 4 Several moments of Sergio's activities collecting and studying insects. A. At Mariana (after attending Congress in Belo Horizonte), Minas Gerais (1983 [with Ubirajara Martins, Magali Hoffmann, Maria Helena Galileo, Sonia Casari, Cleide Costa, Lea Mourgués]). B-C. At Peruíbe, São Paulo (1981 [with Francisco de Abreu, Wanessa Zorzan, Sonia Casari, Luiz Roberto Fontes, Lázaro Silva], 1984 [with Sonia Casari and João Rossi]). D. At Parque Nacional de Emas, Goiás (1984 [with José Sanches, Sonia Casari, Etelvino Bechara]). E. At Parque Nacional da Bocaina, São Paulo (1997 [with Ricardo Pinto-da-Rocha]). F-G. In Bolivia (2008 [with Ubirajara Martins]).

and observing animal life extended to the marine biology field. In some occasions he joined his wife's scientific team in oceanographic cruises to the Brazilian continental shelf on board of the Research Vassel "Prof. W. Besnard" from USP. In those occasions he has even been baptized under Neptune, the god of the Seas, together with the new students on board. He transformed such very funny times in inspiration for colleagues, crew and students that he taught naturally always.

\section{Phylogenetic Systematics}

The study, use and dissemination of systematics concepts, especially phylogenetic systematics, permeated the scientific and teaching career of Prof. Sergio Vanin from the beginning (Fig. 2B). His Doctoral Thesis was the first thesis defended in Brazil (in 1979) using Phylogenetic Systematics (Fig. 2D), having been published in 1986.

Prof. Sergio Vanin was one of the great disseminators of the concepts of Phylogenetic Systematics, both locally and nationally. This dissemination took place during events in which he participated (formally, in lectures, round tables, short courses, etc., and informally), as a guest lecturer in university courses, through the publication in a variety of media outlets, and whenever requested by a student, professional, layman etc.

In the formal context of university teaching, starting in 1986 he taught the graduate course 'Principles of Systematic Zoology' in the IBUSP Zoology program, presenting general concepts of systematics and instruction on executing studies in phylogenetic systematics, from 

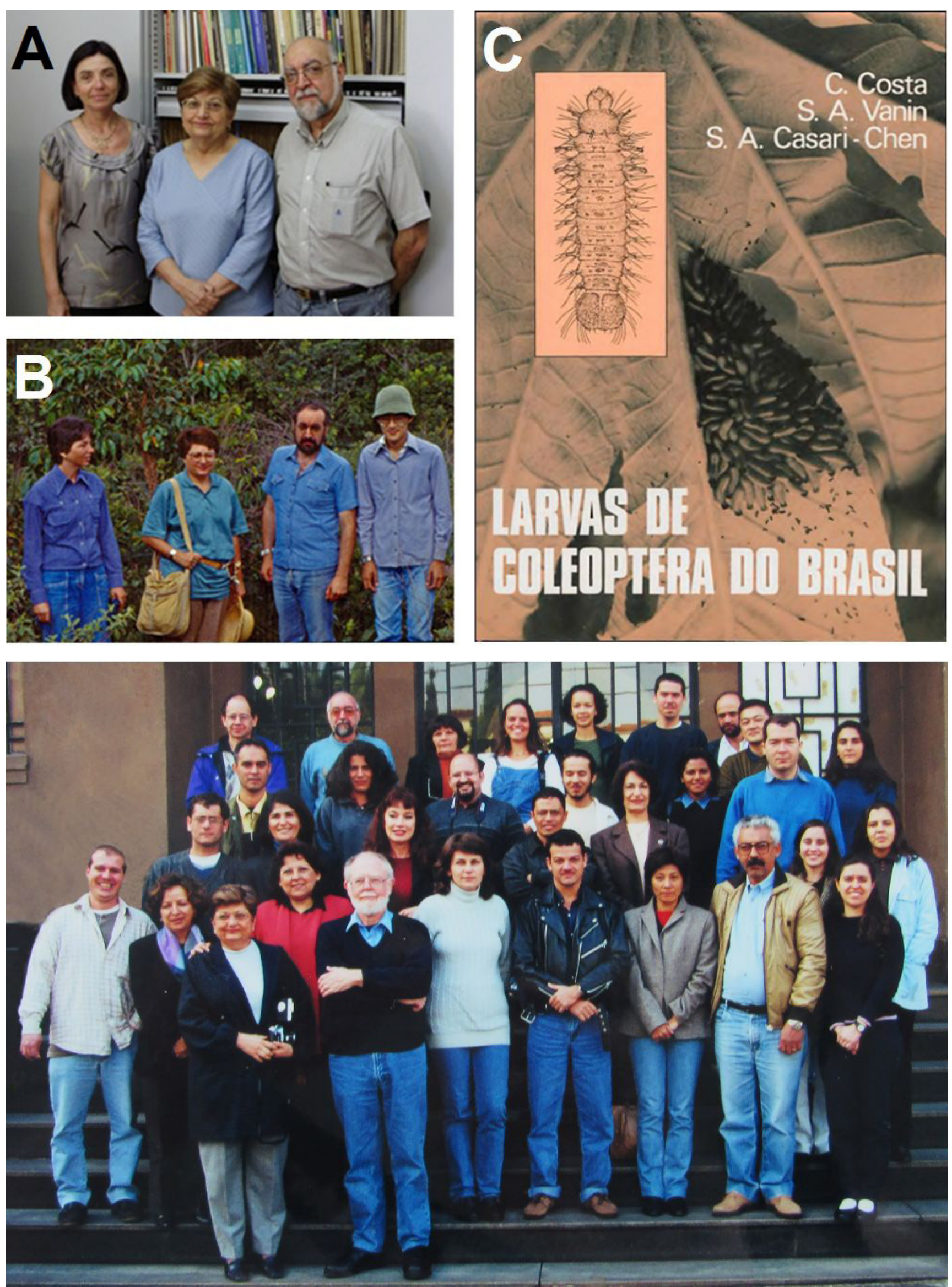

Figure 5 A, Sônia Casari, Cleide Costa and Sergio Vanin. B. The same and Sergio Ide (at Costa Rica, 1987). C. The book by Costa, Vanin and Casari, 1988. Larvas de Coleoptera do Brasil. D. A group photo during the symposium about adults and immatures of Coleoptera, taught at MZUSP by Prof. John Lawrence (front row, sided by Cleide Costa). 

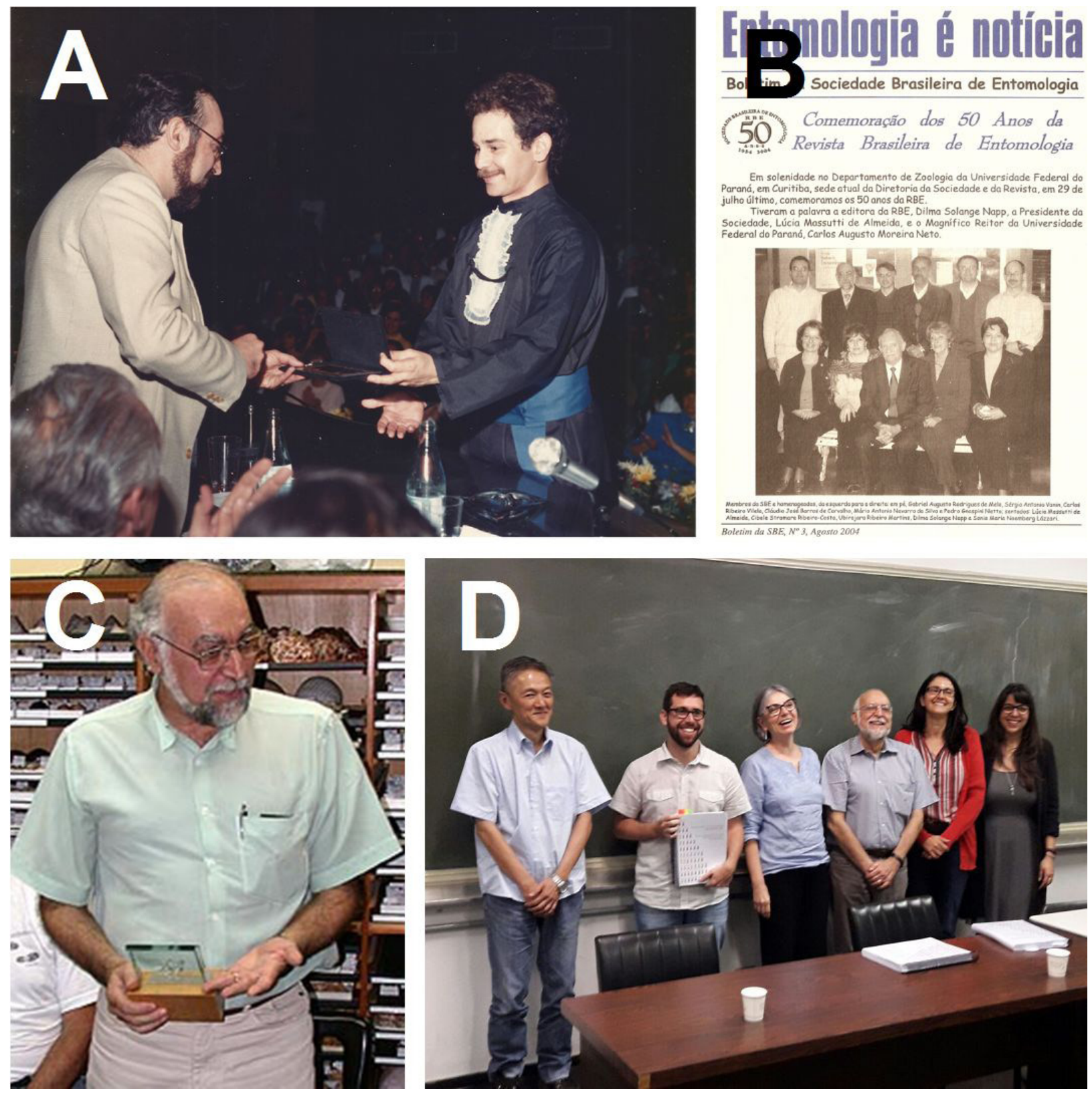

Figure 6 A. Prof. Sergio Vanin receiving his honor plate as Paranymph of the 1987 graduating class of IBUSP [from Pedro Gnaspini]. B. Boletim da Sociedade Brasileira de Entomologia, 2004, celebrating the 50th anniversary of Revista Brasileira de Entomologia) [back line - Gabriel Melo, Sergio Vanin, Carlos Vilela, Cláudio Carvalho, Mário Navarro, Pedro Gnaspini, front line - Lúcia Massutti de Almeida, Cibele Ribeiro-Costa, Ubirajara Martins, Dilma Solange Napp, Sonia Maria Lázzari]. C. Sergio Vanin receiving Prêmio Renato Moscatelli 2005 from the society of Brazilian Conchologists. D. Committee photo after exam to obtain the title of Doctor [Sergio Ide, Gabriel Biffi (applicant), Sonia Casari, Sergio Vanin, Simone Policena Rosa, Laura Rocha Prado, 2017 - all laughing because of a funny comment made by Sergio].

the delimitation of characters and their states to the formal proposal of a taxonomic classification, including considerations for making the necessary nomenclature changes based on a phylogenetic hypothesis. This was the first graduate course in Brazil to teach the concepts of phylogenetic systematics, being founded in 1976 by Nelson Bernardi and transferred to Prof. Sergio Vanin in 1985 by the IBUSP Graduate Commitee.

With the overhaul of the curriculum of the Undergraduate Course in Biological Sciences at IBUSP in the 1990s, he founded the discipline 'Principles of Systematics and Biogeography', participating in its structuring (being nominated by the IBUSP Undergraduate Committee in 1991) and implementation in 1995, and as a professor in the subsequent years (Fig. 3C). This interdepartmental course, taught in collaboration with the Department of Botany at IBUSP to freshmen in the Biological Sciences program, was also the first undergraduate course in Brazil to present the principles of phylogenetic systematics.

\section{Entomology and Taxonomy of Coleoptera}

Prof. Sergio Vanin was dedicated to the study of Coleoptera since the beginning of his scientific career, with approximately 100 publications on the subject (see Appendix 1), including scientific papers and book chapters. Early in his career, he was involved, together with his advisor, Dr. Hans Reichardt, in the study of Myxophaga, especially representatives of the family Torridincollidae (Fig. 2G, 2H), coleopterans that spend their 
whole lives in freshwater, especially in shallow, fast-flowing streams. For his graduate studies, he focused on Curculionoidea, carrying out a taxonomic review of the South American representatives of the family Belidae for his Master's Dissertation (Fig. 2A, 2B) and a taxonomic review and phylogenetic analysis of the curculionid tribe Erodiscini for his Doctoral Thesis (Fig. 2C, 2D). He continued to focus on these taxonomic groups throughout his academic career and worked as a curator-collaborator of the MZUSP Curculionoidea collection until the end of his academic activities, arranging and identifying the specimens of the collection.

Despite the taxonomic focus of his research, Prof. Sergio Vanin's knowledge of insects in general was also excellent, and he advised students working on other groups (see 'Graduate Advisement'). Over the course of his career, he described (in single and coauthored articles, including the results of student advisement) more than 100 species and 13 genera (see Appendix 2).

Prof. Sergio Vanin participated actively in the Brazilian Society of Entomology [Sociedade Brasileira de Entomologia] (SBE) for decades he was a member of the Board of Directors from 1972 to 2000, holding the position of President for five consecutive terms (1986-1996), and was an active member of the editorial board of Revista Brasileira de Entomologia (RBE). SBE had its headquarters at MZUSP until being transferred to the Universidade Federal do Paraná in 2000. During this period, after monthly meetings dealing with the administrative affairs of SBE and RBE, it was a 'mandatory' activity to participate in an often long and always lively fraternization whose stage was a restaurant located two blocks from MZUSP. During these meetings, topics related to what Sergio and Prof. Ubirajara 'Bira' Martins (see Fig. 4G) called "picturesque entomology" were discussed.

In the formal context of teaching, beginning in 1982 he taught 'Basic Entomology' (Fig. 3A), an undergraduate elective, addressing the various insect orders in an evolutionary context. A 'mandatory' and 'highly anticipated' activity by students was the field trip to capture, observe, study and assemble entomological material, always enchanted with many stories and good humor. Undoubtedly, photographs of these activities (e.g., Fig. 3B) are kept in many homes, always with great affection.

\section{The study of immature Coleoptera}

In 1977, Prof. Sergio Vanin began collaborating with Prof. Cleide Costa in a project on "The Metamorphosis of insects of Brazil", a topic that came to include Prof. Sônia Aparecida Casari (also from MZUSP) since 1982 and several collaborators in subsequent years (notably Sergio Ide, first as a student, and now a researcher associated with the Instituto Biológico in São Paulo) (Fig. 5A, 5B). From 1980 to 1986, 38 field trips were made to collect immatures and adults of Coleoptera. Most of these trips were directed a different region of the Atlantic Forest, the Restinga on the coast of São Paulo and the open formations of central Brazil. Each trip with Prof. Sergio Vanin represented the expected extension to the knowledge of nature for the group of accompanying researchers. The material captured in the field was taken to the laboratory at MZUSP to rear the immature specimens in order to obtain the pupa and adult forms, allowing identification at the species level. Plenty of space, dedication and the involvement of several collaborators enabled the success of this great project.

It is worth mentioning the publication of the book 'Larvas de Coleoptera do Brasil' (Costa, Vanin and Casari, 1988 - Fig. 5C), a milestone in the study of immature stages, being internationally recognized and receiving the Alexandre Rodrigues Ferreira Award from the Brazilian Society of Zoology (1989) and the Research Award from the Bunka Research Fund coordinated by Sumitomo Bank and the Brazilian Society of Japanese Culture (1994). This book included the compilation of some previously described immature stages, but it included the original description of a large number of the immature stages of many species. It was also a starting point for other descriptions not only by the group led by these researchers, but also by several other students and researchers in Brazil and other countries. About this book, Prof. Ubirajara R. Martins de Souza (also from MZUSP) remarked: "the greatest importance of pioneering works is the opening of horizons for the deepening of a certain knowledge activity; and, the book on Coleoptera Larvae from Brazil has achieved this purpose". Prof. Sergio Vanin always commented on the importance of this publication and commented with 'pride' (in a good way) that several plates of figures were used in other international publications [one of them by Prof. John Lawrence, who was invited to teach on a symposium about adults and immature of Coleoptera, at MZUSP (Fig. 5D)].

To date, immature stages of almost 180 species distributed among more than 70 families of Coleoptera have been described (see Appendix 3 ).

\section{Student Advisement}

Sergio was a native professor and knew how to inspire students with his enthusiasm and passion for life's evolution. Formally, he mentored seven undergraduate students in Scientific Initiation studies (in course completion studies and / or with scholarships), in addition to a large number of students and 'interns' who underwent some training under his guidance without formal registration. At the graduate level, he oversaw 11 studies to obtain the title of Master and 11 for the title of Doctor (seven of them also in the Master's) (see Appendix 4). He also supervised postdoctoral fellowships.

The research he oversaw focused not only on Coleoptera, but also on other insect orders, such as Odonata, Hemiptera and Lepidoptera, as well as arachnids of the orders Araneae and Opiliones.

The advisement outside Coleoptera occurred when some graduate programs were not yet qualified at the Doctorate level and some zoological groups did not yet have enough of doctors in Brazil to advise new students. As such, Sergio volunteered to help train future doctors in areas that had been largely overlooked in Brazil.

Sergio was always highly dedicated to his advisees and eagerly learned new methods and information that were not part of his previous experiences. An example of this is when he accompanied his first graduate students on their field trips to caves, enduring long hikes and great discomfort with his typically unwavering work, ethic and enthusiasm.

It should be noted that most of the doctors trained by Prof. Vanin are based at teaching and research institutions throughout Brazil where they have founded their own research laboratories.

In addition to formal advisement, the number of informal mentorships and amount of knowledge that was transferred are countless and involved multiple opportunities and institutions. For example, students associated with the MZUSP Coleoptera laboratory liked to talk about their projects with Prof. Sergio Vanin because, in addition to his deep knowledge of the groups, he dealt with the subject with great enthusiasm. He was incredibly happy when students showed him a little-known specimen, and he always had stories about the insect to tell. His almost weekly visits to MZUSP were always highly anticipated by students.

\section{Other activities}

One of the qualities that all people who lived with Prof. Sergio Vanin emphasize when they talk about him is that he was always eager to help. Unless he had a major impediment, he was always willing to participate in evaluation committees, give lectures, etc. Whenever 

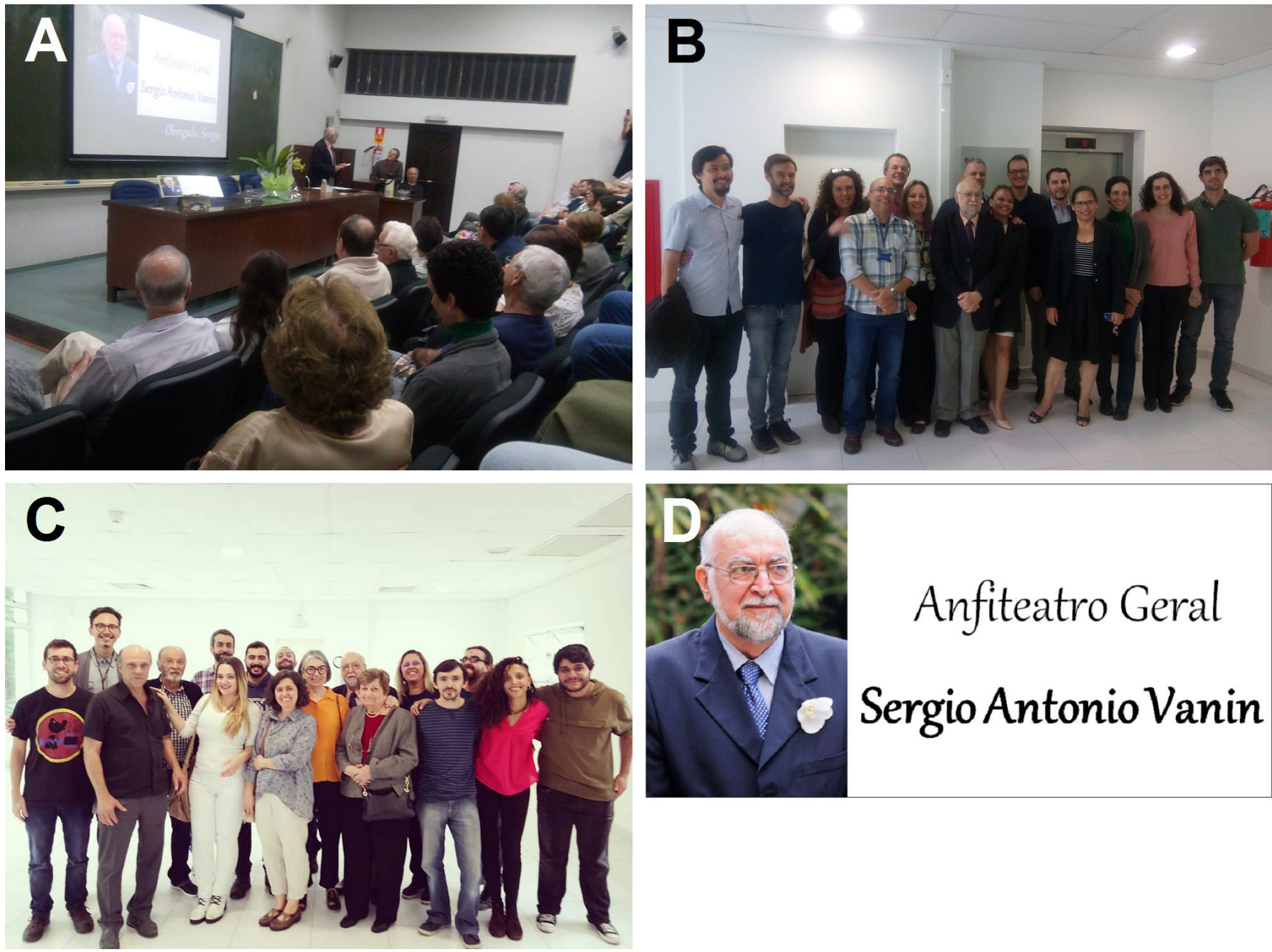

Sergio Antonio Vanin

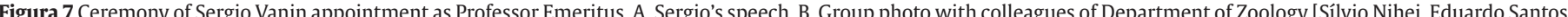

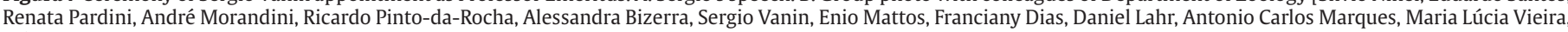

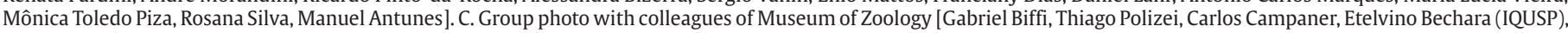

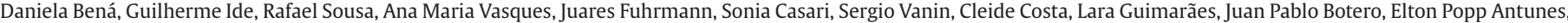
Letizia Migliore e Bruno Zibermann]. D. Plate of the 'Sergio Antonio Vanin Amphitheater'.

he received a visitor in his office, especially when the reason was the identification of biological material, he stopped what he was doing, reached for pertinent bibliography and optical equipment to show and explain the morphological characteristics that could help in the identification of that specimen, and told facts of group's biology and told stories about his experiences with it. He took great pleasure in spreading knowledge.

Prof. Sergio Vanin participated in more than 100 evaluation commitees (academic applications to obtain the titles of Master, Doctor and Associate Professor, qualification exams at the graduate level, public selection for hiring faculty members at Universities [including selection of Full Professor positions], and other evaluations). The audience members have always gained knowledge and thoughtful insights with his comments.

In addition, inside and outside IBUSP and even USP, he acted in several instances and institutions, giving lectures and minicourses, participating in round tables, identifying biological material, giving interviews to the media, and acting as advisor, among numerous other activities generally associated with phylogenetic systematics and entomology.

It should be noted that, in addition to the activities that can be documented, Prof. Sergio Vanin was informally involved with and definitely influenced a large number of scientists both domestically and abroad.

\section{Social interactions and Recognition}

After having participated in the ceremony awarding the title of Professor Emeritus to Prof. Sergio Vanin, Jean Pierre Chauvin (currently a professor in the field of Literature at USP and secretary of the DZ between 1997 and 2007) published an essay (Chauvin, 2018) noting that 'Despite having a powerful voice he commonly projected as a professor, [Sergio] modulated it so as to be heard at low volume, which reflected the tender way in which he related [to other people]' and drawing attention to 'the weighting of acts, great wisdom, respect for differences, sweetness and availability that [Sergio] has always shown to students, employees and colleagues, in any circumstance', which corresponds to a great summary analysis about Sergio.

His posture as a researcher and educator has always captivated those who lived with Sergio, resulting in numerous honors. As a teacher of undergraduates, he was nominated as Honored Professor numerous times throughout his career - he was honored as Paranymph of the 1987 graduating class (Fig. 6A), honored by the 1985, 1988, 1989, 
1991 and 1995 graduating classes, and honored at the Thematic Week of Biology (organized by IBUSP students) in 2014, shortly before retiring from teaching. He also received prizes in recognition of his scientific contribution from the Brazilian Society of Entomology (2004, during the celebration of the 50th anniversary of Revista Brasileira de Entomologia) (Fig. 6B) and the society of Brazilian Conchologists ("Prêmio Renato Moscatelli', 2005)(Fig. 6C). Additionally, he was honored with scientific names in several taxonomic groups (see Appendix 5 and Fig. 2E, 2F).

Sergio had great capacity for work and was always incredibly positive and good humored, being, therefore, an easy person to live together (e.g., Figs. 1G, 6D). As part of the festivities of his appointment as Professor Emeritus (Fig. 7A-C), the amphitheater attached to the Ernst Marcus Building of IBUSP (in which Sergio participated in several activities as a student and as a teacher) was named the 'Sergio Antonio Vanin Amphitheater' (Fig. 7D). Whenever you pass by, we invite you to look at his photo and remember Sergio.

Surely, wherever he went Sergio made an enormous and enduring contribution. We are thankful for having had the opportunity to share part of our lives with him.

\section{Acknowledgements}

We are deeply indebted to Taran Grant (IBUSP) for the English version of our text, and to Ana Maria S. P. Vanin for the comments and photographs. We also thank a long list of people (impossible to name all), mainly colleagues and students from IBUSP and MZUSP, who knew Sergio Vanin and contributed with information and photographs.

\section{Conflicts of interest}

The authors declare no conflicts of interest.

\section{References}

Anderson, R. S., 1999. New species of Sicoderus Vanin from the Virgin Islands (Coleoptera; Curculionidae; Curculioninae; Otidocephalini). Tijdschr. Entomol. 141 (1-2), 129-135. http://dx.doi.org/10.1163/2211943499900009.

Chauvin, J. P., 2018. Três dimensões de um mestre. Available in: https:// portogente.com.br/noticias/opiniao/104919-tres-dimensoes-deum-mestre?fbclid=IwAR1 sXVeXfMkzMonb8kiwb2hdGjojwvA 3j_UihrwqZ7OhES6JnQ16gzaAw60 (accessed 11 December 2020).

Mermudes, J. R. M., 2006. A new species of Dicordylus Lacordaire, 1863 from Brazil (Coleoptera, Belidae, Pachyurinae, Agnesiotidini), with a new record of D. serranus Vanin 1976 for Brazil. Pap. Avulsos Zool. 46(8), 73-75. http://dx.doi.org/10.1590/S0031-10492006000800001.

Vanin, S.A., 1976. Taxonomic revision of the South American Belidae (Coleoptera). Arquivos de Zoologia, 28, 1-75.

Vanin, S.A., 1986. Systematics, cladistic analysis, and geographical distribution of the tribe Erodiscini (Coleoptera, Curculionidae, Otidocephalinae). Revista Brasileira de Entomologia, 30, 427-670.

Vanin, S. A., 2011. Torridincolidae: Torrent Beetles. Available in: http:// tolweb.org/Torridincolidae/9050 (accessed 11 December 2020).

Wikimedia, 2020. Available in: https://upload.wikimedia.org/wikipedia/ commons/b/b1/Sicoderus_vanini_lateral.jpg(accessed 11 December 2020). 


\section{Supplementary material}

The following online material is available for this article:

Appendix 1 - List of publications including research papers, textbooks, book chapters and diffusion papers.

Appendix 2 - Described taxa (genera and species) [all in Coleoptera] (the numbers between [] refer to the papers listed in Appendix 1, in which the taxa listed here were described).

Appendix 3 - Described Coleopteran larvae (the numbers between [] refer to the papers listed in Appendix 1, in which the taxa listed here were described).

Appendix 4 - Supervision of Graduate students and Post-Docs.

Appendix 5 - Species named in honor of Sergio A. Vanin. 